\title{
Evaluation of Normal Abdominal Organs by Diagnostic Imaging in the Premature Miniature Pig
}

\author{
Jinhwa Chang, Joohyun Jung, Sunkyoung Oh and Mincheol Choi* \\ Department of Medical Imaging, College of Veterinary Medicine, Seoul National University, Seoul, 171-542, Korea \\ Received November 25, 2008 / Accepted January 19, 2009
}

\begin{abstract}
This report describes the normal radiographic and ultrasonographic morphological features of premature minipigs at 4, 8, 12 and 20 weeks of age. Radiographic examination is a simple diagnostic method used to identify the general morphologic state of major organs and their adjacent structures, and to assess the presence of abnormalities. The parameters for evaluation in plain abdominal radiographs are the degree of diffuse serosal margin details, extent of visualization of each organ, their size, shape, and contour, locations of main organs - such as the liver, stomach, spleen, kidneys, urinary bladder - the distribution of the intestines, and assessment of the retroperitoneal space and its contents. Ultrasonographic examinations are used to investigate their internal condition. The parameters for evaluation in abdominal ultrasonography are echogenicity, echotexture, and size and shape of the main organs such as the liver, spleen, kidney, urinary bladder and gastrointestinal tract. Minipigs had similar findings compared to dogs or cats.
\end{abstract}

Key words : Premature minipig, radiography, ultrasonogphy, abdominal organ

\section{Introduction}

Due to the growing demand for organs in human transplantation, organ shortage has been a chronic problem [6]. One recent alternative to solve this problem is xenotransplantation of animal organs. Xenotransplantation is the transplantation of living organs from one species to another such as from pigs to humans [2]. Pigs are currently thought to be the best candidates for organ donation because they are readily available, their organs are anatomically comparable in size to humans, and new infectious agents are less likely since they have been in close contact with humans through domestication for many years [1]. In particular, transgenic and minipig (Micro-pigs ${ }^{\circledR}$, PWG Genetics Korea, Ltd.) which have high genetic and physiologic similarities to humans, have been developed as human models $[2,8]$. There has been, however, little information published on the structural anatomy of miniature pigs. The purpose of this study is to explore normal states of the abdominal organs using diagnostic imaging tools such as radiography and ultrasonography, and then provide basic data for various experiments using minipigs.

\footnotetext{
*Corresponding author

Tel : +82-2-880-1278, Fax : +82-2-880-8662

E-mail : mcchoi@snu.ac.kr
}

\section{Materials and Methods}

\section{Animals}

Healthy and premature minipigs at 4, 8, 12, and 20 weeks of age were used in this study. Number of examined minipigs by each age was as follows; in total 47 minipigs on radiographic study and 37 minipigs on ultrasonographic study (Table 1). All animals were obtained from the PWG Genetics Korea, Ltd. PWG micro-pig ${ }^{\circledR}$ were raised under strict SPF barrier system and microbiologically well defined conditions. The minipigs were individually housed indoors in cages, fed dry pig food, and provided with water ad libitum.

\section{Methods}

The minipigs were fasted for at least about two to three days prior to evaluation of the abdomen through radiography and ultrasonography. The blood screening tests are within normal values. General sedation was induced with an intramuscular injection of tiletamine plus zolazepam $\left(\right.$ Zoletil $\left.^{\circledR}\right)$, at a dose of $4 \sim 8.8 \mathrm{mg} / \mathrm{kg}$ five minutes before the procedures for 12 and 20 week-age minipigs [3,4]. A standard radiographic examination of minipig abdomen was performed at two different positioning, a right lateral and a ventrodorsal projection.

Ultrasonography of the abdomen was also performed in dorsal recumbency, and gently restricted by assistants holding the fore and hindlimbs and using a V-trough pad after radiographic study. It was inspected about morphologic 
Table 1. Number of examined minipigs at various ages

\begin{tabular}{|c|c|c|c|c|}
\hline No. Age & 4-week & 8-week & 12-week & 20-week \\
\hline Radiography & 13 & 8 & 9 & 17 \\
\hline Ultrasonography & 8 & 11 & 9 & 9 \\
\hline
\end{tabular}

criteria of internal organs in minipigs, excluding their function such as motility of the gastrointestinal tract and characteristics of main abdominal vessels that affects the anesthetic drug on ultrasonographic study.

\section{Results}

Abdominal radiographic findings in minipigs at 4 , 8,12 and 20 weeks of age

There is usually a loss of serosal details throughout the abdominal cavity in young animals. However, it is possible to see the caudoventral hepatic angle and the renal shadow towards the cranial part of retroperitoneal space on the later-
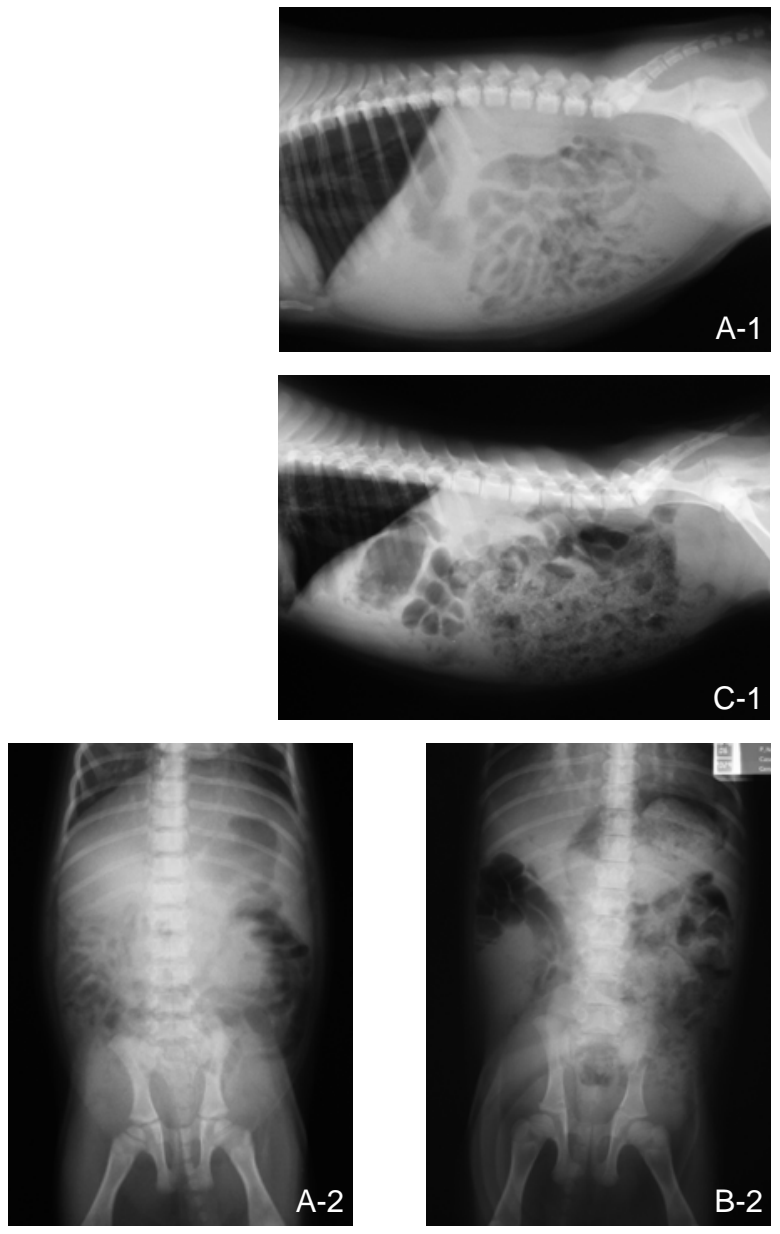

Fig. 1. Minipig abdominal radiographs at 4 (A-1 and A-2), 8 (B-1 and B-2), 12 (C-1 and C-2) and 20 (D-1 and D-2) weeks of age. al view in minipigs at 4 weeks of age (Fig. 1. A-1, A-2). Abdominal serosal detail of minipigs at 8 weeks of age is generally similar to those at 4 weeks of age; however, it may be additionally identified in the margin of the spleen in the four out of eight minipigs (Fig. 1. B-1, B-2).

It begins to show with the urinary bladder image in the three out of nine minipigs at 12 weeks of age (Fig. 1. C-1, $\mathrm{C}-2)$. The triangular-shaped spleen is seen in the mid-abdominal region on lateral and ventrodorsal views. In most case, the contour of the right kidney is more clearly seen than the left beginning at the level of the $1^{\text {st }}$ lumbar vertebra down to the $3^{\text {rd }}$ lumbar vertebra in minipigs at 20 weeks of age (Fig. 1. D-1, D-2). The right kidney is located on similar position to the left kidney in the abdominal region. Abdominal organs such as the liver, stomach, intestines and urinary bladder are more clearly seen as compared to those in 12 week old minipigs.

Generally, the stomach is located in the middle to the left of midline on VD view. That is, its median plane divides
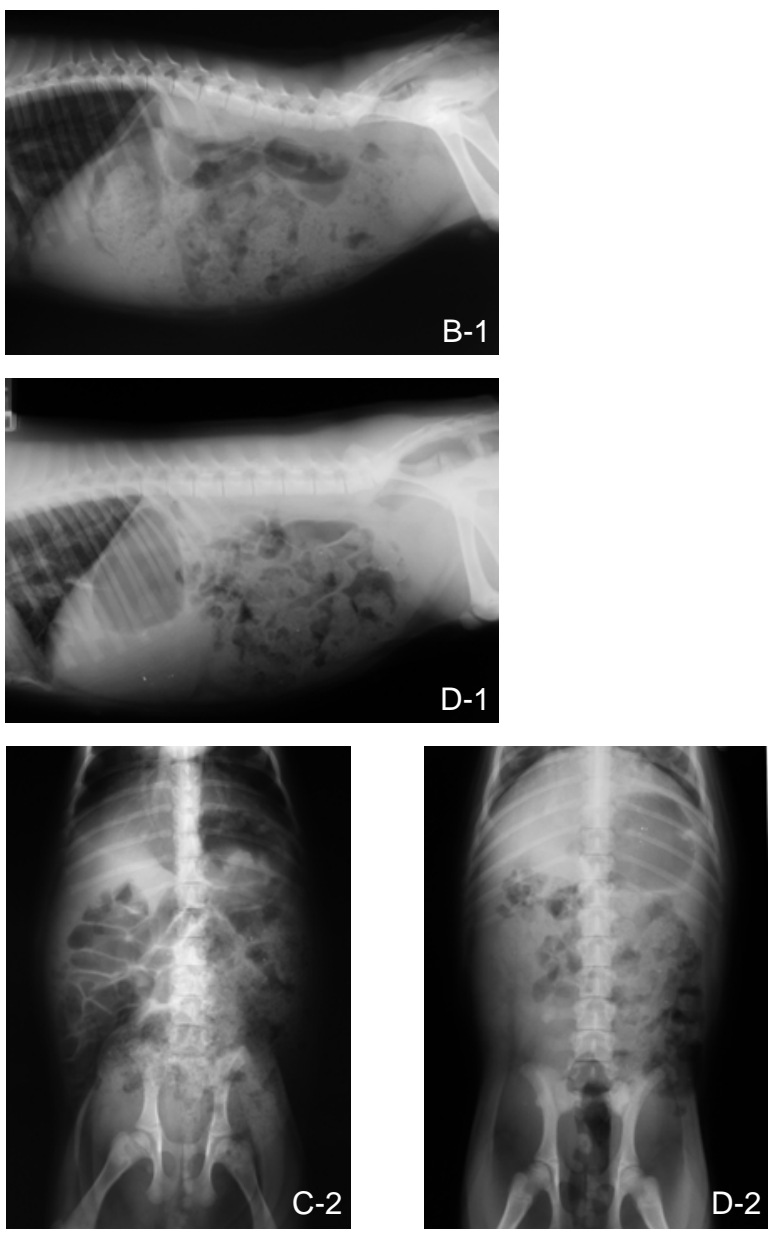
the moderately filled stomach in such a way that the fundus and body are on the left and the relatively small pyloric part is on the right. Taken together, the abdominal serosal details gradually became clearer on radiographs as the minipig grows older, so it is possible to observe the contour, shape, location and distribution of main abdominal organs. However, because of the unique and coiling intestinal structures which are filled with gas and ingesta, and are located in the mid to caudal abdominal cavity region, making an exact assessment and evaluation of the main organs in minipigs can be difficult.

Minipig abdominal ultrasonography at 4, 8, 12 and 20 weeks of age

The liver forms extensive cranial relationships with the diaphragm and, is bounded caudally by the small intestines and at times, the ascending colon on the right, and the stomach and spleen on the left. The liver parenchyma is homogeneously echogenic and has echogenicity of medium texture (Fig. 2-A). Anechoic round and tubular vascular structures are noted, representing hepatic and portal veins. Portal veins have more echogenic walls than the hepatic veins because of less organized connective tissue within the vessel walls. The gallbladder is seen as an anechoic, round to oval structure (Fig. 2-A). It is located between the right medial and quadrate lobe when scanned just to the right of midline. Its wall is poorly seen or appears as a thin line in minipigs.
The spleen is located in the left cranial abdominal region and usually follows the greater curvature of the stomach. It is long, narrow, lying flat, and is nearly dorsoventrally oriented similar to the arrangement in dogs. The splenic parenchyma is homogeneous with a finely textured, mediumto high-level echo pattern (Fig. 2-C). The usual crescent or triangular shape of the spleen seen in the near field is variable, and its capsule is smooth, regular, and echogenic to hyperechoic.

The kidney is flatted dorsoventrally and has somewhat elongated poles (Fig. 2-D). The hilus of the kidney is situated in the medial border. The renal pelvis is long and consists of a central cavity and two large recesses which are directed toward the poles. The renal medulla is the least echogenic, followed by the renal cortex (Fig. 2-D). The urinary bladder has anechoic luminal contents and varies in size and position depending on its urine volume (Fig. 2-F).

The stomach of the minipigs is easily recognized by its size, regular peristaltic activity and by the presence of rugae (Fig. 2-B). The stomach and small intestines have five wall layers including the lumen-mucosal interface; the hypoechoic, thick mucosa; the thin echogenic submucosal layer; a thin hypoechoic muscle layer; and the thin echogenic outer serosal layer. Their intestines, however, is poorly visualized and evaluated due to the extremely thin and collapsed wall thickness compounded by the large amount of gaseous contents (Fig. 2-E).
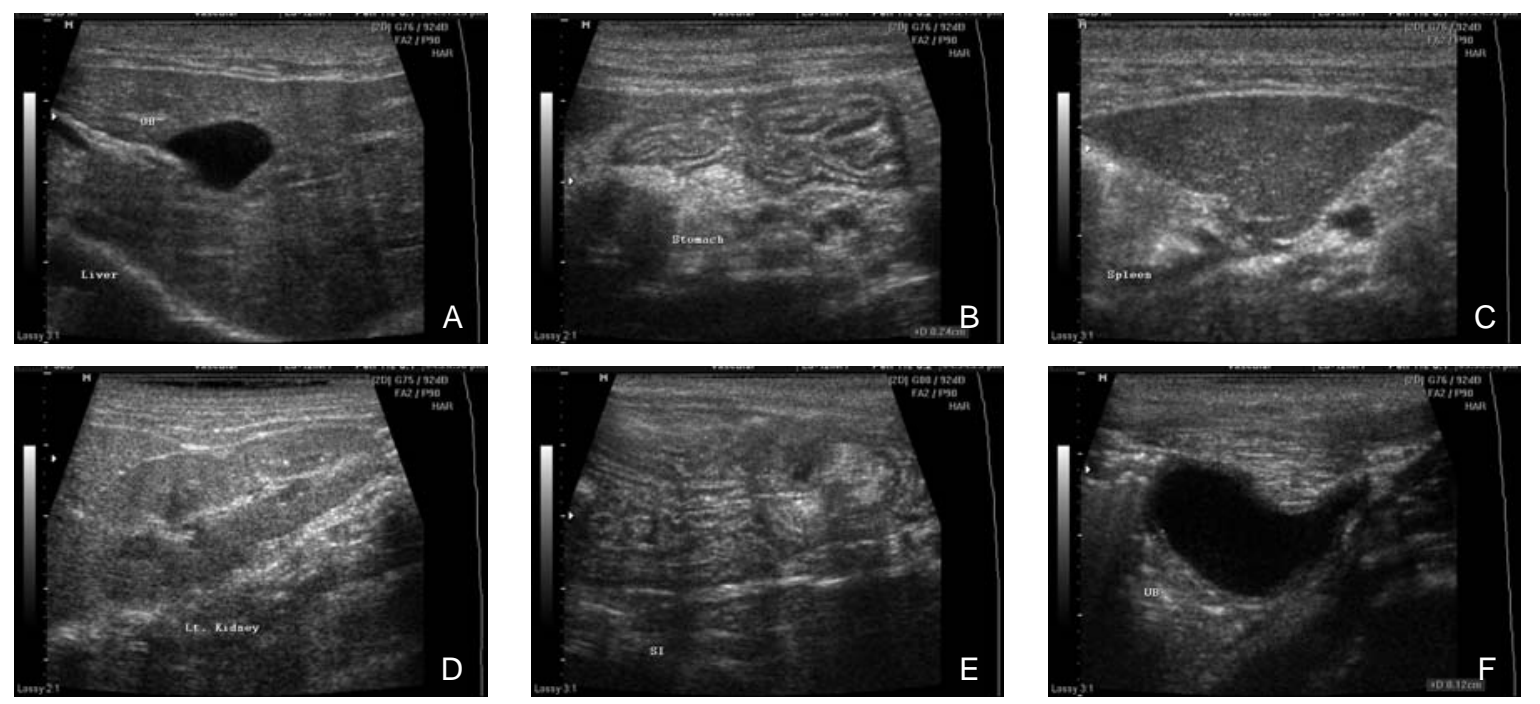

Fig. 2. Minipig abdominal ultrasonographs. A: liver and gallbladder; the round, anechoic, fluid-filled, thin-walled gallbladder and surrounding liver tissue. B: stomach; empty stomach with visibly folded gastric wall. C: spleen; a finely textured echogenic parenchyma with triangular shape. D: left kidney; outer less echogenic renal cortex and inner hypoechoic renal medulla. E: small intestine; emptying small intestine with thin wall layering. F: urinary bladder; mildly distended with anechoic urine. 
Table 2. Major ultrasonographic values of abdominal organs in minipigs

\begin{tabular}{|c|c|c|c|c|}
\hline Items Age & 4-week & 8-week & 12-week & 20-week \\
\hline Thickness of the gastric wall & $0.17 \pm 0.04$ & $0.21 \pm 0.06$ & $0.31 \pm 0.10$ & $0.25 \pm 0.04$ \\
\hline Length of the left kidney & $4.39 \pm 0.41$ & $4.80 \pm 0.52$ & $5.95 \pm 0.93$ & $7.05 \pm 0.61$ \\
\hline Width of the left kidney & $1.73 \pm 0.26$ & $1.91 \pm 0.26$ & $2.16 \pm 0.31$ & $2.63 \pm 0.41$ \\
\hline Length of the right kidney & $4.37 \pm 0.31$ & $4.91 \pm 0.43$ & $6.01 \pm 0.85$ & $6.98 \pm 0.61$ \\
\hline Width of the right kidney & $1.62 \pm 0.45$ & $1.78 \pm 0.18$ & $2.07 \pm 0.23$ & $2.78 \pm 0.23$ \\
\hline Thickness of the UB wall & $0.13 \pm 0.06$ & $0.18 \pm 0.06$ & $0.24 \pm 0.08$ & $0.18 \pm 0.08$ \\
\hline
\end{tabular}

${ }^{*}$ Mean \pm SD (cm)

The size and wall thickness of each organ were determined and normal standard values of each organ were established through ultrasonographic examin (Table 2).

\section{Discussion}

The radiographic examination is not an ideal method for assessment of the abdomen in minipigs. It is especially less informative in minipigs due to the characteristic coiling arrangement of intestinal structures dominating most of the mid-to-caudal abdominal cavity [5]. The mass effect upon intestinal structures and poor preparation of experimental animals leaving large amounts of gaseous and fecal contents within the distended intestines resulted in non-visualization of superimposed other abdominal structures. In spite of these structural limitations, it can be used as a screening tool for providing a rough overview of the distribution, location and contour of each organ.

The liver, gallbladder and urinary bladder of the minipigs are similar in location and position as those of dogs [5], although these two species are not at all closely related. There are, however, a few differences in details between them. First, centrally are the short quadrate lobe and a caudate process of the liver which does not make contact with the right kidney as is the case in other domestic mammals [5]. Second, the stomach is J shaped, a little more acutely angled, with the pylorus located closer to the midline similar to cats, whereas the dogs' stomach is U shaped, with the pylorus located towards the left [7]. Third, the abdominal cavity is occupied mostly by intestinal structures filled with gaseous contents which are crowded towards the mid-to-caudal abdominal region. This characteristic is consistent with the nature of omnivores' intestines with fermentation occurring within the small intestines and the relatively longer intestines compared to other small animals. Forth, minipigs have a narrow retroperitoneal space compared to dogs and cats and the renal shadow can only be observed cranially between the level of the $1^{\text {st }}$ and $3^{\text {rd }}$ lumbar vertebrae. Lastly, since very young minipigs, such as 4 weeks of age, have a little more intraperitoneal fat compared other animals, better abdominal details allow visualization of the caudoventral hepatic angle and renal shadow.

Ultrasonographic examination is useful to understand the internal architecture of main organs and judge their abnormalities. Ultrasonographic findings of minipigs are similar to those of dogs with regard to the location, shape, echogenicity and echotexture of each organ. The normal relationship of the echogenicity of each organ is important for recognizing major abnormalities. In the normal minipigs, splenic parenchyma is most echogenic compared with the cortex of the left kidney and liver, and echogenicity of the renal cortex is similar to or slightly less than that of normal liver parenchyma at approximately the same depth.

Echogenicity and texture of the liver, gallbladder, spleen, and urinary bladder are similar to small animals such as dogs and cats. Ultrasonographic descriptions of kidneys are characteristic because of their elongated and flattened shape and are similar to the human kidney [5].

It is difficult to evaluate wall layering of the intestines due to the thinness of the intestinal wall, its unique coiling arrangement, and gas interference. There are limitations for scanning older minipigs due to the large amount of fat and a big body conformation.

The present study provides general characteristics of the different abdominal organs in the minipig using diagnostic imaging methods. The normal fundamental information for each organ could be useful and essential for further investigation of application towards various disease models.

\section{Acknowledgement}

This work was supported by a grant (2007 0401034006) 
from BioGreen 21 Program, Rural Development Administration, Republic of Korea.

\section{References}

1. Dooldeniya, M. and A. Warrens. 2003. Xenotransplantation: where are we today? J. R. Soc. Med. 96, 111-117.

2. French, A. J., J. L. Greenstein, B. E. Loveland, and P. S. Mountford. 1998. Current and future prospects for xenotransplantation. Reprod. Fertil. Dev. 10, 683-696.

3. Gray, C. W., M. Brush, and C. C. Beck. 1974. Clinical experience using CI-744 in chemical restraint and anesthesia of exotic specimens. J. Zoo. Anim. Med. 5, 12-21.
4. John C. T., J. T. William, and G. J. Benson. 1996. Lumb $\mathcal{E}$ Jones' Veterinary Anesthesia, pp. 273-274, 3rd eds., Williams \& Wilkins, Baltimore, MD.

5. Sack, W. O. 1982. Essentials of pig anatomy pp. 29-45,1st ed., Cornell University, Ithaca, NY.

6. Stephen, P. S. 1997. Genetically modified animal organs for human transplantation. World J. Surg. 21, 939-942.

7. Thrall, D. E. 2007. Textbook of veterinary diagnostic radiology, pp. 750-769, 4th eds., Saunders, Philadelphia, PA.

8. Vodicka, P., K. Jr. Smetana, B. Dvorankova, T. Emerick, Y. Z. Xu, J. Ourednik, V. Ourednik, and J. Motlik. 2000. The miniaturepig as an animal model in biomedical research. Ann. N. Y. Acad. Sci. 1049, 161-171.

\section{초록 : 미성숙 미니돼지에서 방사선과 초음파를 이용한 복부장기의 평가}

\section{장진화 · 정주현 · 오선경 · 최민철*}

(서울대학교 수의과대학 영상의학과)

$4,8,12,20$ 주령의 미성숙 미니돼지에서 방사선과 초음파를 이용하여 복부 주요 장기의 형태학적 특징을 살펴보 았다. 방사선 검사는 전반적인 장기의 형태를 확인하는 데 이용되는 가장 기본적이고 단순한 방법이다. 기본 복부방 사선 사진에서 이용되는 평가해야 할 항목들은 우선 전반적인 복부세부음영의 정도, 간, 위, 비장, 신장, 방광, 장들의 위치, 크기, 형태, 변연, 후복강 평가이다. 초음파 검사는 이러한 주요 장기들의 내부 실질을 평가하는 데 주로 사용된다. 미니돼지는 개와 고양이와 비교했을 때 유사한 소견을 가진 것을 확인하였다. 